Acta vet. scand. $1970,11,390-393$.

From the Department of Reproductive Physiology and Pathology,

Veterinary College of Norway, Oslo.

\title{
ABORTION IN SOWS
}

\author{
By \\ John Aamdal
}

\begin{abstract}
Abortion in sows is described by a number of authors (Roberts 1956, Bennet 1960, Dunne \& Hokanson 1963). Abortion may be caused by non-infectious conditions and a number of infectious agents. The most common infectious conditions are leptospirosis, brucellosis (Brucella suis) and erysipelas, and abortion also occurs in connection with some virus diseases. Of the noninfectious conditions nutritional disturbances and poisoning seem to be most common.
\end{abstract}

\section{MATERIALS AND METHODS}

Artificial insemination in pigs has been used to some extent in Norway from 1956. Informations about the results of A.I. are obtained by questionaires in which the farmers report whether the sow became pregnant and if she farrowed or aborted. Based on these questionaires informations of 31,766 pregnancies were collected during 12 years. In total 465 pregnancies were interrupted by abortion, i.e. $1.46 \%$.

Table 1 shows that there is some difference from year to year in the frequency of abortions, but the difference is not significant.

Table 2 gives a survey of abortions in sows inseminated in different seasons of the year. Highest number of sows are inseminated in the winter season (December-January-February), and in this period the frequency of abortion is lowest $(1.32 \%)$. Lowest number of insemination and highest frequency of abortion $(1.85 \%)$ appear in the summer season (June-July-August). The difference between seasons is significant.

During the years a number of boars were used in A.I. Sixtyeight of these had more than 100 pregnancies, and in Table 3 is 
T a ble 1. Abortion in the years 1956-1968.

\begin{tabular}{lccc}
\hline Year & $\begin{array}{c}\text { No. of } \\
\text { pregnancies }\end{array}$ & $\begin{array}{c}\text { No. of } \\
\text { abortions }\end{array}$ & $\begin{array}{c}\text { Abortion } \\
\text { in \% }\end{array}$ \\
\hline 1956 & 893 & 18 & 2.02 \\
1957 & 2,343 & 37 & 1.58 \\
1958 & 2,291 & 30 & 1.30 \\
1959 & 3,471 & 66 & 1.90 \\
1960 & 3,986 & 58 & 1.46 \\
1961 & 3,924 & 50 & 1.27 \\
1962 & 2,443 & 51 & 2.09 \\
1963 & 2,273 & 28 & 1.23 \\
1964 & 1,487 & 15 & 1.00 \\
1965 & 2,196 & 30 & 1.37 \\
1966 & 2,654 & 31 & 1.17 \\
1967 & 2,787 & 40 & 1.43 \\
1968 & 1,018 & 11 & 1.08 \\
\hline Total & 31,766 & 465 & 1.46 \\
\hline
\end{tabular}

No significant difference between years (P $\left.0.90<\chi^{2}<P 0.95\right)$.

Table 2. Variation in frequency of abortion in sows inseminated in 4 seasons of year.

\begin{tabular}{llcccc}
\hline $\begin{array}{l}\text { Inseminated } \\
\text { in }\end{array}$ & $\begin{array}{c}\text { No. of } \\
\text { pregnancies }\end{array}$ & $\begin{array}{c}\text { No. of } \\
\text { abortions }\end{array}$ & $\begin{array}{c}\text { Abortion } \\
\text { in \% }\end{array}$ & $\begin{array}{c}\text { No. of } \\
\text { pregnancies } \\
\text { in \% of total }\end{array}$ \\
\hline SPRING & $\begin{array}{l}\text { March } \\
\text { April } \\
\text { May }\end{array}$ & 7,606 & 110 & 1.45 & 23.9 \\
\hline SUMMER & $\begin{array}{l}\text { June } \\
\text { July } \\
\text { August }\end{array}$ & 6,363 & 118 & 1.85 & 20.0 \\
\hline AUTUMN & $\begin{array}{l}\text { Sept. } \\
\text { Oct. } \\
\text { Nov. }\end{array}$ & 6,594 & 89 & 1.35 & 20.8 \\
\hline WINTER & $\begin{array}{l}\text { Dec. } \\
\text { Jan. } \\
\text { Feb. }\end{array}$ & 11,203 & 148 & 1.32 & 35.3 \\
\hline & & 31,766 & 465 & 1.46 & \\
\hline
\end{tabular}

Significant difference between seasons as to frequency of abortion (P $0.95<\chi^{2}<$ P 0.98). 
T a b l e 3. Variation in frequency of abortion for 68 boars with more than 100 litters.

\begin{tabular}{lcccccccc}
\hline $\begin{array}{l}\text { Abortion } \\
\text { in \% }\end{array}$ & $\begin{array}{l}0.00- \\
0.49\end{array}$ & $\begin{array}{l}0.50- \\
0.99\end{array}$ & $\begin{array}{l}1.00- \\
1.49\end{array}$ & $\begin{array}{l}1.50- \\
1.99\end{array}$ & $\begin{array}{l}2.00- \\
2.49\end{array}$ & $\begin{array}{l}2.50- \\
2.99\end{array}$ & $\begin{array}{l}3.00- \\
3.49\end{array}$ & $\begin{array}{c}\text { Total no. } \\
\text { of preg- } \\
\text { nancies }\end{array}$ \\
\hline No. of boars & 5 & 18 & 13 & 12 & 12 & 6 & 2 & 17,498 \\
\hline
\end{tabular}

Statistic analysis showed no significant difference between boars.

T a b l e 4. Time of abortion in gestation period.

\begin{tabular}{|c|c|c|c|c|c|c|}
\hline \multicolumn{2}{|c|}{ Aborted 28-59 d. } & \multicolumn{2}{|c|}{ Aborted 60-89 d. } & \multicolumn{2}{|c|}{ Aborted 90-105 d. } & \multirow{2}{*}{$\begin{array}{c}\text { Total no. of } \\
\text { abortions }\end{array}$} \\
\hline no. & $\%$ & no. & $\%$ & no. & $\%$ & \\
\hline 65 & 44.5 & 55 & 37.7 & 26 & 17.8 & 146 \\
\hline
\end{tabular}

T a b l e 5. Causes of abortion in 253 cases.

\begin{tabular}{|c|c|c|c|c|c|c|c|c|}
\hline \multicolumn{2}{|c|}{$\begin{array}{l}\text { Erysipelas } \\
\text { suis }\end{array}$} & \multicolumn{2}{|c|}{$\begin{array}{c}\text { Non- } \\
\text { infectious } \\
\text { diseases }\end{array}$} & \multicolumn{2}{|c|}{$\begin{array}{l}\text { Spoiled } \\
\text { food }\end{array}$} & \multicolumn{2}{|c|}{$\begin{array}{l}\text { Abortion } \\
\text { without } \\
\text { any previous } \\
\text { symptoms }\end{array}$} & \multirow[t]{2}{*}{$\begin{array}{c}\text { Total } \\
\text { no. of } \\
\text { abortions }\end{array}$} \\
\hline no. & $\%$ & no. & $\%$ & no. & $\%$ & no. & $\%$ & \\
\hline 23 & 9.3 & 5 & 2.0 & 4 & 1.6 & 216 & 87.0 & 248 \\
\hline
\end{tabular}

shown that there are only small differences between boars as far as the frequency of abortion is concerned. Statistical analysis also shows that the difference is not significant.

Abortion occurred at different times of the gestation period (Table 4). Of 146 abortions with exact indication of time $44.5 \%$ occurred between 28 and 59 days of pregnancy, $37.7 \%$ between 60 and 89 days and $17.8 \%$ between 90 and 105 days of pregnancy.

Based on the information collected through questionaires a survey of the causes of abortion is given in Table 5. Of 248 abortions $23(9.2 \%)$ were caused by acute erysipelas suis. These abortions occurred a few days after the sows became ill. Five ( $2 \%$ ) sows aborted in connection with illness of various etiologies. Spoiled food was the cause in $4(1.6 \%)$ abortions. In the largest group $(87 \%)$, however, the sows showed no symptoms previous to abortion. 


\section{DISCUSSION}

Abortion in pigs is comparatively seldom in Norway and occurs only in $1.46 \%$ of the pregnancies. The most important reason for this low frequency may be that Norway is free from infectious diseases, such as leptospirosis, brucellosis and swine fever, and nutritional deficiency is not a common cause of abortion.

\section{REFERENCES}

Bennet, P. C.: Differential diagnostic methods for abortion in swine. Proc. 64th Ann. Meet. U.S. Livestock Sanit. Ass., Charleston 1960, 414-417.

Dunne, H. W. \& J. F. Hokanson: A modern approach to abortion and stillbirth problems in swine. Sci. Proc. 100th Ann. Meet. Amer. vet. med. Ass. 1963, 54-59.

Roberts, S. J.: Veterinary obstetrics and genital diseases. ed. Edwards Brothers, Inc. Ann. Arbor, Michigan, 1956.

\section{SUMMARY}

Of a total of 31,766 pregnancies 465 abortions were reported, in average $1.46 \%$.

By comparison of the frequency of abortion at different times of the year a significantly higher percentage of abortion was found in sows inseminated during the summer months. No significant difference was found between 68 boars as to the frequency of abortion. In 248 abortions $23(9.3 \%)$ aborted due to acute erysipelas suis, 5 due to non-infectious diseases, 4 due to spoiled food, but $216(87.0 \%)$ sows aborted without any previous symptoms.

\section{SAMMENDRAG}

Abort hos purke.

I forbindelse med A.I. på gris har forfatteren samlet opplysninger om abort. Materialet omfatter 31.766 drektigheter, og av disse ble 465 avbrutt av abort, d.v.s. 1,46\%. Ved sammenligning av kastningsfrekvensen $i$ de ulike årstider fant en at frekvensen var høyest $i$ månederne juni-juli-august. I alt 68 råner hadde over 100 drektigheter, og ved sammenligning av kastningsfrekvensen for de enkelte ble det ikke funnet signifikant skilnad. Kastningene er $i$ dette materiale jevnt fordelt på hele drektighetstiden.

Årsak til kastning var flere, slik som akutt rødsyke $(9,3 \%)$, alvorlige sykdomstilstander $(2 \%)$, skadet fór $(1,6 \%)$, men st $\varnothing$ rst var gruppen som kastet uten forutgående symptomer på sykdom $(87 \%)$. 